\title{
ДОСЛІДЖЕННЯ ХІМІЧНОГО СКЛАДУ ВОДИ ОКРЕМИХ ПРИРОДНИХ ДЖЕРЕЛ КУРОРТУ СХІДНИЦЯ
}

\begin{abstract}
На території Східницького природного родовища налічується 38 джерел мінеральних вод типу "Нафтуся" і понад 17 бурових свердловин з різним фізико-хімічним складом води та ще понад 25 джерел залишаються не вивченими дотепер. Важливою інформацією для ефективного використання мінеральних вод є їхній хімічний склад, умови зберігання, механізми впливу та фізіологічні особливості обмінних процесів у людському організмі. Наведено результати експериментальних досліджень щодо вивчення хімічного складу деяких природних джерел курорту Східниця та зроблено їх порівняльний аналіз. Проведено відбір проб води із окремих таких джерел на території селища міського типу Східниці та підібрано методики дослідження їхнього хімічного складу згідно з вимогами Держстандарту. Експериментально визначено органолептичні показники окремих малодосліджених природних джерел курорту Східниця, значення яких знаходяться в межах норми. Досліджено фізико-хімічні властивості води цих джерел, а саме: загальна твердість води, сухий залишок, вміст йонів $\mathrm{Ca}^{2+}, \mathrm{Mg}^{2+}$, $\mathrm{Fe}^{2+}, \mathrm{K}^{+}, \mathrm{Na}^{+}, \mathrm{Cl}^{-}, \mathrm{HCO}_{3}^{-}$та $\mathrm{pH}$, оцінено їхній кількісний розподіл. На основі аналізу отриманих експериментальних даних можна рекомендувати проаналізовані східницькі природні джерела не тільки як ресурси питної води, але як такі, що містять мінеральні й біологічно-активні речовини, тому їх можна вживати із лікувальною метою.
\end{abstract}

Ключові слова: мінеральна вода "Нафтуся"; органолептичні показники; мінералізація; катіонно-аніонний склад, лікувальні та оздоровлювальні властивості.

Вступ. На сучасному етапі розвитку суспільства, коли істотними стають екологічні проблеми, дедалі більше людей вважають доцільним використовувати мінеральну воду для споживання та приготування їжі. Тому стає очевидним той факт, що у місцевостях, де є природні джерела мінеральних вод, невідкладним завданням є розширення і вдосконалення мережі лікувальних закладів, широке використання природних лікувальних факторів для профілактики й лікування різних захворювань. Важливу роль у цьому відіграють колосальні ресурси лікувальних мінеральних вод, освоєння яких у нашій країні щороку зростає. Особливу увагу привертають слабомінералізовані води, найвідомішим представником яких є мінеральна вода "Нафтуся" (Bazar, 2004; Boychuk, 2003; Petrovs'ka, 2005; Fedorenko, 2002). "Нафтуся" - це гідрокарбонатна, кальцієвомагнієва вода, слабкої мінералізації із біологічно активними речовинами органічного походження - бітумами. Мінеральні води типу "Нафтуся" варто розглядати як складні багатокомпонентні істинні розчини. У Східниці ще повністю не вивчено 25 джерел, які мають високий вміст органічних речовин, це незаперечний факт їх лікувальних властивостей. Варто було б продовжити наукові дослідження таких цінних джерел, як № 2c, 12, 21, 22, 118, 357. Тому ми поставили за мету провести експериментальні дослідження щодо вивчення хімічного складу і власти- востей окремих природних джерел Східниці та зробити порівняльну характеристику за органолептичними показниками та мінеральним складом.

Матеріал і методи дослідження. Органолептичні властивості води поділяють на 2 підгрупи: 1) фізико-органолептичні - сукупність органолептичних ознак, що сприймаються органами чуття і оцінюються за інтенсивністю сприйняття та 2) хіміко-органолептичнівміст певних хімічних речовин, здатних подразнювати рецептори відповідних аналізаторів і викликати ті чи інші відчуття (Zinchuk, 2000; Caballero, 2016; Kukurudza, 1994).

3anax - це здатність наявних у воді хімічних речовин випаровуватись i, створюючи відчутний тиск пари над поверхнею води, подразнювати рецептори слизових оболонок носа і синусних пазух, чим спричиняти відповідне відчуття. Розрізняють: природні (ароматичний, болотяний, гнильний, рибний, трав'яний і т. ін.), специфічні (аптечний) і невизначені запахи.

Смак і присмак - здатність наявних у воді хімічних речовин після взаємодії зі слиною подразнювати смакові сосочки, розташовані на поверхні язика, і зумовлювати відповідне відчуття. Розрізняють солоний, гіркий, кислий і солодкий смаки. Решта - присмаки: лужний, болотний, нафтопродуктів, металічний і т. ін. Неприємні запахи, смаки і присмаки води обмежують ії

\section{Інформація про авторів:}

Гвоздецька Галина Володимирівна, канд. хім. наук, доцент, кафедра біології і xiмiї. Email: galyna.gv@gmail.com Старчевський Михайло Казимирович, д-р хім. наук, професор, кафедра біології і хімії. Email: starchevskyi.mk@gmail.com Прийма Андрій Мирославович, канд. хім. наук, доцент, кафедра біології і хімії. Email: pryima.am@gmail.com

Цитування за ДСтУ: Гвоздецька Г. В., Старчевський М. К., Прийма А. М. Дослідження хімічного складу води окремих природних джерел курорту Східниця. Науковий вісник НЛтУ України. 2019, т. 29, № 1. С. 74-77.

Citation APA: Gvozdetska, G. V., Starchevskyi, M. K., \& Pryima, A. M. (2019). Chemical Composition of Some Water Sources of the Natural Resort Shidnytsia. Scientific Bulletin of UNFU, 29(1), 74-77. https://doi.org/10.15421/40290116 
споживання і примушують шукати інші джерела, які можуть виявитися небезпечними в епідемічному і хімічному відношенні. Запах води підземних джерел може бути зумовлений сірководнем, колодязів - деревом зрубу. Ці речовини можуть бути біологічно активними, небайдужими для здоров'я, мати алергенні властивості, $\epsilon$ показниками ефективності очищення води на водопровідних станціях (Fedorenko, 2002; Fomenko, 2007; Fo$\min , 2004)$.

Кольоровість - природна властивість води, зумовлена гуміновими речовинами, які вимиваються 3 грунту під час формування поверхневих та підземних водойм і надають воді жовто-коричневого забарвлення. Кольоровість вимірюють у градусах за допомогою спектрофотометрів та фотоколориметрів шляхом порівняння із забарвленням розчинів хромово-кобальтової чи платиново-кобальтової шкали (Nabyvanets', 2007).

Каламутність - природна властивість води, зумовлена вмістом завислих речовин органічного і неорганічного походження (глини, мулу, органічних колоїдів, планктону і т. ін.). Каламутність вимірюють нефелометрами, спектрофотометрами та фотоколориметрами за імітуючою каоліновою шкалою, яка є набором суспензій білої глини каоліну у дистильованій воді. Каламутність води вимірюють у мг/л шляхом порівняння її оптичної щільності зі щільністю стандартних суспензій каоліну, згідно 3 ДСанПіН 383 - у нефелометричних одиницях каламутності (НОК) (Nabyvanets', 1986).

Протилежна характеристика води - прозорість здатність пропускати світлові промені. Прозорість вимірюють за методом Снеллена: воду наливають у циліндр з плоским дном, на відстані 4 см від дна розміщують стандартний шрифт 3 літерами заввишки 4 мм, завтовшки - 0,5 мм, воду з циліндра зливають доти, поки через іï стовпчик можна буде прочитати літери. Висота цього стовпчика у сантиметрах і характеризує прозорість води (Nabyvanets', 1986, Nakorchevs'ka, 2003).

Сухий залишок (мінералізація загальна) - це кількість розчинених речовин, переважно (90 \%) мінеральних солей, в 1 л води. Воду із сухим залишком до 1000 мг/л називають прісною, від 1000 до 3000 мг/л солонуватою, понад 3000 мг/л - солоною. Оптимальною вважають мінералізацію на рівні 300-500 мг/л. Воду із сухим залишком 100-300 мг/л вважають задовільно мінералізованою, 500-1000 мг/л - підвищено, але допустимо мінералізованою.

Водневий показник (рН) - природна властивість води, зумовлена наявністю вільних іонів Гідрогену. Вода більшості поверхневих водойм має $\mathrm{pH}$ у межах від 6,5 до 8,5. pН підземних вод коливається в діапазоні від 6 до 9. Кислими $(\mathrm{pH}<7)$ є болотяні води, багаті на гумінові речовини. Лужними ( $\mathrm{pH}>7)$ - підземні води, що містять багато гідрокарбонатів (Nabyvanets', 1986).

Твердість загальна - природна властивість води, зумовлена наявністю так званих солей твердості, а саме: кальцію і магнію (сульфатів, хлоридів, карбонатів, гідрокарбонатів та ін.). Розрізняють загальну, тимчасову та постійну й карбонатну твердість. Тимчасова, або гідрокарбонатна, твердість зумовлена гідрокарбонатами $\mathrm{Ca}^{2+} \mathrm{i} \mathrm{Mg}{ }^{2+}$, які під час кип'ятіння води перетворюються на нерозчинні карбонати та випадають в осад.

Постійною називають твердість, яка залишається після години кип'ятіння води і зумовлена наявністю хлоридів і сульфатів $\mathrm{Ca}^{2+}$ i $\mathrm{Mg}^{2+}$, які не випадають в осад. Загальну твердість води виражають у мгекв/л. Воду із загальною твердістю до 3,5 мг-екв/л $\left(10^{\circ}\right)$ вважають м'якою, від 3,5 до 7 мг-екв/л (10-20 $)$ - помірно твердою, від 7 до 10 мг-екв/л $\left(20-28^{\circ}\right)$ - твердою і понад 10 мг-екв/л $\left(28^{\circ}\right)$ - дуже твердою.

Вміст солей твердості понад 7 мг-екв/л надає воді гіркого смаку. У районах зі спекотливим кліматом користування водою з високою твердістю призводить до перебігу сечокам'яної хвороби (Nakorchevs'ka, 2003). Солі впливають на органолептичні ознаки води - надають їй солоного (хлориди) чи гіркого (сульфати) смаку. Хлориди, котрі надходять у водойми зі стічними водами промислових підприємств, наприклад металургійних, не мають нічого спільного $з$ одночасним органічним та бактеріальним забрудненням (Petrovs'ka, 2005).

Під час застосування хімічних методів аналізу води велике значення відводять правильному відбору проб води. Існують загальні вимоги до відбору проб: проба повинна відображати умови, місце та мету ії відбору; відбір, зберігання та доставка проб до лабораторії повинні забезпечувати незмінність у вмісті відповідних хімічних компонентів; об'єм проби повинен бути достатнім для наступного іï аналізу. Місце для відбору проб вибирають відповідно до мети аналізу на основі вивчення місцевості. Визначаючи місце відбору проб води для хімічного аналізу, особливо ретельно потрібно обстежити притоки річки та джерела їх забруднень, що розташовані вище від місця відбору проби (Boyaryn, 2001).

Результати дослідження та їх обговорення. На території Східницького родовища налічується 38 джерел мінеральних вод типу "Нафтуся" і понад 17 бурових свердловин з різним фізико-хімічним складом води та понад 25 джерел не вивчено. Територія розміщення джерел - 8 км². Ресурси мінеральної води - 80-100 м³ за добу. Оскільки Східниця розташована в Орівському пласту Сколівських Карпат, вода у природних джерелах стикається із нафтою і має специфічний присмак. Мінеральна вода формується в надрах землі, а в сполученні 3 органічними речовинами і мікроелементами утворює ефект своєї цілющої сили.

За мінералізацією та хімічним складом Східницькі мінеральні води можна поділити на такі типи:

- унікальні лужні (содові) мінеральні води типу "Боржомі", середньої мінералізації (8-11 г/л).

- слабомінералізовані води (мінералізація до 1 г/л) 3 підвищеним вмістом органічних речовин та джерела з більш вираженою жовчогінною дією.

- слабомінералізовані залізисті води (мінералізація до 0,5 г/л).

- хлоридно-натрієві води (мінералізація від 35 до 100 г/л і більше) з підвищеним вмістом брому.

Окрім них на території Східниці є родовища природньо-столових вод і гліцеринові джерела.

"Нафтуся" - це гідрокарбонатна, кальцієвомагнієва вода, слабкої мінералізації із біологічно активними речовинами органічного походження - бітумами. Лікувальні та оздоровлювальні властивості "Нафтуся" мають широкий спектр:

- сечогінна, жовчогінна, спазмолітична, знеболювальна дія; стимуляція функції нирок;

- нормалізація діяльності ШКТ (шлунково-кишкового тракту) та підшлункової залози, залоз внутрішньої секреції, відновлення клітин печінки, заспокоєння запальних процесів; 
- виведення каменів із нирок, сечо- та жовчовивідних шляхів, жовчного міхура та запобігання їхньому утворенню;

- очищення організму від шлаків, токсинів, радіонуклідів;

- імуномоделювальні властивості.

У мінеральних водах контролюють різноманітні показники якості, але найголовнішими серед них є показники іонного складу. Для цього застосовуються різні хімічні та фізико-хімічні інструментальні методи. Передусім визначають аніонний та катіонний склад. До складу цієї мінеральної води входять такі елементи, як натрій, калій, кальцій, магній, гідрокарбонати, хлориди, сульфати, сірководень, кремнієва кислота, марганець, мідь, літій, залізо, бром, йод. Нафтове походження проявляється у легкому присмаку нафти та запаху сірководню.

Одним із основних завдань, які поставлено у нашій роботі, є дослідити хімічний склад окремих малодосліджених природних джерел типу "Нафтуся" і на основі отриманих результатів дослідження дати порівняльну характеристику окремих показників хімічного складу води із відомих лікувальних джерел.

Для дослідження хімічного складу та органолептичних показників відібрали проби із шести природних джерел - 2c, 12, 21, 22, 118, 357 смт Східниця. Проби було відібрано 13.04.2016 р., 22.04.2016 р., 12.05 .2016 р. До кожної проби складали супровідний документ, в якому наводили інформацію про час та місце відбору проб.

Хімічний склад цих проб досліджували на відповідність ДСТУ 4808:2007 "Джерела централізованого питного водопостачання. Гігієнічні та екологічні вимоги щодо якості води і правила вибирання", за такими показниками: твердість води, сухий залишок, рН та вміст йонів $\mathrm{Ca}^{2+}, \mathrm{Mg}^{2+}, \mathrm{Cl}^{-}, \mathrm{HCO}_{3}^{-}, \mathrm{Fe}^{2+}, \mathrm{K}^{+}, \mathrm{Na}^{+}$. Результати наших досліджень наведено в таблиці.

Таблиця. Результати визначення органолептичних показників джерел Східниці

\begin{tabular}{|c|c|c|c|c|c|c|c|c|c|}
\hline \multirow{2}{*}{ № $3 / \Pi$} & \multirow{2}{*}{ Назва показника } & \multirow{2}{*}{ Од. } & \multicolumn{6}{|c|}{ Джерела води } & \multirow{2}{*}{$\begin{array}{l}\text { Норма } \\
\text { ДСТУ }\end{array}$} \\
\hline & & & $2 \mathrm{c}$ & 12 & 21 & 22 & 118 & 357 & \\
\hline 1 & Сухий залишок & МГ/Л & $345,1(2)$ & $300,2(3)$ & $140,1(2)$ & $88,5(2)$ & $298,2(3)$ & $93,0(5)$ & $\leq 1000$ \\
\hline 2 & Запах & В.од. & 3 & 4 & 2 & 2 & 3 & 3 & 2 \\
\hline 3 & Каламутність & HOM & $1,0(5)$ & $1,5(5)$ & $1,0(5)$ & $1,0(5)$ & $1,0(5)$ & $1,0(5)$ & 1,5 \\
\hline 4 & Смак і присмак & В.од. & 4 & 3 & 3 & 2 & 4 & 3 & 2 \\
\hline 5 & Загальна твердість & мГ-екВ/Л & $3,1(2)$ & $4,3(3)$ & $2,1(2)$ & $1,6(2)$ & $2,9(2)$ & $0,9(2)$ & $\leq 7$ \\
\hline 6 & Залізо загальне & МГ/Л & $1,40(2)$ & $0,27(2)$ & $6,12(3)$ & $4,95(2)$ & $1,80(2)$ & $4,10(2)$ & $\leq 0,3$ \\
\hline 7 & Кальцій & МГ/Л & $34,07(2)$ & $66,13(5)$ & $16,03(3)$ & $18,03(2)$ & $48,09(4)$ & $7,01(3)$ & - \\
\hline 8 & Магній & МГ/Л & $17,02(2)$ & $25,53(3)$ & $29,79(2)$ & $17,63(2)$ & $2,43(1)$ & $6,68(2)$ & - \\
\hline 9 & Гідрокарбонати & МГ/л & $498,5(4)$ & $405,5(5)$ & $85,4(2)$ & $170,8(2)$ & $476,7(4)$ & $171,1(3)$ & - \\
\hline 10 & Хлориди & мГ/Л & $2,50(2)$ & $<1,0$ & $<1,0$ & $<1,0$ & $<1,0$ & $2,05(2)$ & $\leq 250$ \\
\hline 11 & Калій & мГ/л & $1,75(3)$ & $1,54(2)$ & $0,92(2)$ & $1,62(3)$ & $1,71(4)$ & $1,59(2)$ & - \\
\hline 12 & Натрій & МГ/Л & $12,02(2)$ & $20,80(3)$ & $<1,0$ & $<1,0$ & 10,5 & $<1,0$ & - \\
\hline 13 & $\mathrm{pH}$ & $\mathrm{pH}$ & $7,80(2)$ & $7,15(2)$ & $6,05(2)$ & $5,56(2)$ & $7,25(2)$ & $6,90(2)$ & $6-9$ \\
\hline
\end{tabular}

Визначення вмісту катіонів $\mathrm{K}^{+}, \mathrm{Na}^{+}$у досліджуваних пробах проводили в лабораторії промислової токсикології на відповідність ДСТУ 4808:2007 "Джерела централізованого питного водопостачання. Гігієнічні та екологічні вимоги щодо якості води". Загальну твердість визначали відповідно до ГОСТ 4151 (GOST 4151), сухий залишок - ГОСТ 18164 (GOST 18164), залізо загальне - ГОСТ 4011 (GOST 4011), гідрокарбонатиГОСТ 1030-81 (GOST 1030-81), хлориди - ГОСТ 4245 (GOST 4245). Експериментально визначили органолептичні показники досліджуваних джерел та порівнювали отримані результати на відповідність ГОСТ 2874-82 "Питна вода. Гігієнічні вимоги до якості води" (GOST 2874-82). Визначення органолептичних показників води досліджуваних джерел показало, що за всіма показниками їх можна використовувати для споживання як питну воду, незважаючи на легкий запах сірководню i присмак нафти.

Висновки. Проведено відбір проб води із джерел № 2c, 12, 21, 22, 118, 357 на території смт Східниця та підібрано методики дослідження їх хімічного складу відповідно вимог Держстандарту. Експериментально визначено органолептичні показники окремих, малодосліджених, природних джерел смт Східниця та досліджено фізико-хімічні властивості: $\mathrm{pH}$, загальну твердість, сухий залишок, вміст йонів $\mathrm{Ca}^{2+}, \mathrm{Mg}^{2+}, \mathrm{Cl}^{-}, \mathrm{HCO}_{3}^{-}, \mathrm{Fe}^{2+}$, $\mathrm{K}^{+}, \mathrm{Na}^{+}$.

На основі аналізу отриманих експериментальних даних щодо визначення хімічного складу вод досліджуваних природних джерел можна вважати, що великих відмінностей у основних показників немає. Щодо загальної твердості води, то найбільша вона в джерел № 22 і
357. Ці дані узагальнюються із вмістом солей Сa i Mg. Найбільше заліза є у воді № 2c, 12 і 118. У складі води № 12, 21, 22 і 118 - дуже мало йонів хлору, у джерел № $21,22,357$ - йонів натрію. Вода із джерел № 21 і 22 має слабокислу реакцію, джерела № 357 - нейтральну, а вода із свердловини № 2с і джерел № 12, 118 - слаболужну. Отже, ці джерела можна рекомендувати не лише як резерв питної води, але завдяки наявності мінеральних i біологічно активних речовин їх можна вживати із лікувальною метою.

\section{Перелік використаних джерел}

Bazar, M. V. (2004). Shidnytsia. Drogobych: Kolo. [In Ukrainian].

Boyaryn, A. Yu. (2001). Laws of rational use of water resources. Drogobych: Kolo. [In Ukrainian].

Boychuk, Yu. D., Soloshenko, E. M., Bugai, O. V. (2003). Ecology and environmental safety. Sumy: VTD Universytetska knyga. [In Ukrainian].

Caballero, B., Finglas, M., \& Toldra, F. (2016). Encyclopedia of food and health mineral water: types of mineral water. Waltham, MA: Academic Press.

Fedorenko, V. I., \& Kirjakin, T. I. (2002). Drinking water bottling. Moscow: Mir. [In Russian].

Fomenko, N. V. (2007). Recreational resources and health resorts. Kyiv: Centr navchalnoyi literatury. [In Ukrainian].

Fomin, G. F. (2004). Control of chemical, bacterial and radiation safety of water according to international standards. Moscow: Mir. [In Russian].

GOST 1030:81. Water for domestic and drinking purposes. Methods of analysis. [In Russian].

GOST 18164:72. Drinking water. Method for determination of the dry residue content. [In Russian].

GOST 4011:72. Drinking water. Methods for measuring the mass concentration of total iron. [In Russian]. 
GOST 4151-72. Drinking water. Method for determining the total hardness. [In Russian].

GOST 4245-72. Drinking water. Methods for determination of chloride content. [In Russian].

Kukurudza, S. P. (1994). Determination of the quality of natural waters. Lviv: Vydavnychyy centr LNU im. I. Franka. [In Ukrainian].

Nabyvanets, B. Y., \& Osadchyy, V. I. (2007). Analytical chemistry of surface water. Drohobych: Kolo. [In Ukrainian].

Nabyvanets, B. Y., Sukhan, V. V., \& Kalabina, L. V. (1986). Analytical chemistry of the natural environment. Kyiv: Lybid. [In Ukrainian].
Nakorchevska, V. F., \& Arhatenko, T. V. (2003). Water chemistry and microbiology. Kyiv: KNUBA. [In Ukrainian].

Petrovska, M. A. (2005). Water protection. Lviv: Vydavnychyy centr LNU im. I. Franka. [In Ukrainian].

Stotska, H. O. (1997). Healing water of Skhidnytsia. Lviv: Chervona Kalyna. [In Ukrainian].

Tsvyatkov, V. I. (2005). Live water in the Zolota Bania. Lviv: Spolom. [In Ukrainian].

Zinchuk, V. K., \& Levytska, G. D. (2000). Laboratory Workshop on Analytical Chemistry. Optical analysis methods. Lviv: Vydavnychyy centr LNU im. I. Franka. [In Ukrainian].

G. V. Gvozdetska, M. K. Starchevskyi, A. M. Pryima Drohobych Ivan Franko State Pedagogical University, Drohobych, Ukraine

\section{CHEMICAL COMPOSITION OF SOME WATER SOURCES OF THE NATURAL RESORT SHIDNYTSIA}

There are 38 sources of mineral water such as "Naftusia" in the Shidnytsia territory, and more than 17 wells have different physical and chemical composition of water, more than 25 sources are not well investigated yet. The area of those sources are about $8 \mathrm{~km}^{2}$. Resources of mineral water produce from 80 to 100 cubic meters per day. Mineral water is formed in the ground and in combination with organic substances and trace elements creates the effect of its strong healing power. For salinity and chemical composition mineral water can be divided into the following types: unique alkaline (soda) type mineral water "Borjomi", secondary mineralization $(8.11 \mathrm{~g} / \mathrm{l})$, brackish water (salinity of $1 \mathrm{~g} / \mathrm{l})$ with high content of organic substances and sources with more pronounced choleretic effect, mineralized ferruginous water (mineralization up to $0.5 \mathrm{~g} / \mathrm{l}$ ), sodium chloride, water (salinity from 35 to $100 \mathrm{~g} / \mathrm{l}$ and more) with high content of bromine. Medicinal properties of "Naftusia" cover a wide range: diuretic, choleretic, spasmolytic, analgesic effect; stimulation of kidney function; normalization of the gastrointestinal tract (gastrointestinal tract) and pancreas, endocrine glands, liver cell renewal, soothe inflammation; removing stones (small size) of the kidneys, urinary and biliary tract, gall bladder and prevent their formation; cleanse the body of toxins, toxins, radionuclides; immunomodulating properties. In the mineral waters different quality controls are necessary, but the most important among them is the distribution of the ions. Different chemical and physical-chemical instrumental methods, were used for this. First, the anionic and cationic composition were determined. The composition of the mineral water includes elements such as sodium, potassium, calcium, magnesium, bicarbonates, chlorides, sulfates, hydrogen sulfide, silica, manganese, copper, lithium, iron, bromine, iodine. Oil origin appears in a light oil taste and smell of hydrogen sulfide. Samples of water from sources № 2c, 12, 21, 22, 118, 357 on the territory of the village Skhidnytsia were chosen to study their chemical composition in accordance with the requirements of State Standard. Organoleptic parameters were experimentally determined of natural waters village Shidnytsia. The physical and chemical properties were studied $-\mathrm{pH}$, total hardness, dry residue content and ion $\mathrm{Ca}^{2^{+}}$, $\mathrm{Mg}^{2+}, \mathrm{Cl}^{-}, \mathrm{HCO}_{3}^{-}, \mathrm{Fe}^{2+}, \mathrm{K}^{+}, \mathrm{Na}^{+}$. Under the analysis of experimental data were obtained, one can recommend Shidnytsia water sources, not only as a reserve of drinking water, but also those that contain important mineral and biologicallyactive substances so they can be used with therapeutic purposes.

Keywords: mineral water "Naftusia"; organoleptic parameters; mineralization; cationic anionic composition; medical and therapeutic properties of water. 